\title{
THE SHRINKING RATE OF UTILISED AGRICULTURAL LAND AND ITS COMPONENTS IN THE BALTIC SEA REGION COUNTRIES
}

\author{
ANGELIJA BuČIENĖ ${ }^{1}$
}

Klaipėda University (Lithuania)

\begin{abstract}
The temporal and spatial changes of land use are important while studying the rural landscapes on both the regional-geographical and environmental scales. In the Baltic Sea region with nine countries (including Russian Federation, represented by Kaliningrad oblast, the utilised agricultural land (UAL) makes about $34 \%$ of total region area on the average. The current research revealed the trends of different shrinking rate of UAL in nine studied countries from 1993 to 2008: it varied within the range between $3 \%$ in Denmark and $43 \%$ in Estonia. Research focus was given to the changes in ratio between arable land and area under meadows and pastures: it increased from 6.5 to 10.9 during 15 years period (1993-2008) on the average, that shows the increase in land use and farming intensity even the UAL area was shrunk. KEY WORDS: utilised agricultural land, arable land, meadows and pastures, shrinking rate.
\end{abstract}

JEL CODES: Q 16, Q 15.

\section{Introduction}

Agriculture is shaping most of the European landscapes and it is diverse, ranging from intensively farmed monocultures that put heavy pressure on the environment, to extensively farmed semi-natural areas creating much less pressure (Mücher, Wascher, 2007: 38). One of the problems is land abandonment, which is already a common phenomenon in regions where agricultural productivity is relatively low (Baldock et al., 1996). The shrinking of agricultural land is natural, where agriculture is becoming less important as economic activity, or where the soils are less favored, either the urbanisation level is high. However when looking from the world perspective, the agricultural land resources in many areas of our Planet are limited, the recent agricultural land is particularly important to be utilised as much as the soil fertility allows. The situation is particularly worrying in the central and Eastern Europe, where political and economic change has negatively affected the conditions for farming (EEA, 2004). This is evident in the south-eastern Baltic sea coast region too: during the last 20 years the farming has experienced tremendous changes after the collapse of Soviet Union in 1991 and during the transition to market economy period in Estonia, Latvia, Lithuania, Kaliningrad oblast of Russian Federation (RF), Poland and Eastern Germany (Korneevets, 1997: 23; Bučienè, 2002: 15; Dobele, 2004: 34; Contemporary changes..., 2008: 7, 21; Agriculture, Fisheries, 2012: 3; Vinokurov, 2007: 120-122; Celevaja programma..., 2006: 51-52). New membership in EU has made the impact on the farming and land use as well, since many of farmers, particularly elder, could choose to farm further or not. With more sustainable development of rural landscapes and more rational usage of land, its important to carry on all forms of farming, involving more younger people from the countryside and making life there more attractive (Europe in figures, 2009; Bučiené,

Angelija Bučienè - Klaipėda University, Department of Social geography, prof. dr., scientistic interest: agroecological, environmental and social geographical aspects of rural landscapes in the Baltic Sea region.

E-mail: angelija.buciene@ku.lt

Tel.:+37046398661 
2003: 158). Thus it was important to focus not only on quantitative, but also on qualitative changes of rural landscapes (Andersen, 2003; Nikodemus et al., 2010). The aim of this research was to analyse the shrinking rate of utilised agricultural land (UAL) and its components and to reveal the trends of agricultural land use and farming intensity in nine Baltic Sea region countries during 1993-2008 period.

\section{Materials and methods}

It is not easy to make a sustainability assessment of rural landscapes with different land use, farming intensity, etc. due to the complexity of structural elements and their inwrought relations (Sustainable agriculture, 2012: 43). Our research in Lithuania has revealed that leaching of nitrate nitrogen via drainage runoff is almost 10 times higher from the arable crop plots, than from the permanent long term pasture on the average (Bučienè, 2009: 13). Other research in the Baltic region also has shown the same trends (Towards a Baltic Sea..., 2007). Thus the ratio between arable and grassland areas is important from the sustainability point of view. In this research the attempt was done to focus on the trends of changes of UAL and its components: arable land area, area under the meadows and pastures and their ratio.

After the compilation of agricultural land use data, the main trends in time and space were revealed. The studied countries were grouped in accordance to the main trend of land use change. Four types of UAL shrinking rate trends in the research region during the period from 1993-1995 to 2005-2008 were determined: 1) Countries where the UAL decreased a little in the area; 2) Countries where the UAL decreased on the average from 10 to $20 \%$; 3) Countries where the UAL decreased from 20 to $30 \%$; 4). Countries where the UAL decreased more than $30 \%$.

According to the ratio of arable land and area under the meadows and pastures, countries were grouped into the 4 groups: 1) Countries where this ratio decreased mostly; 2) Countries where the ratio remained as it was or slightly decreased; 3) Countries where the ratio increased from 10 to $20 \%$; 4) Countries where the ratio increased more than $20 \%$.

The research region - nine Baltic Sea region countries: Latvia, Estonia, Finland, Sweden, Denmark, Germany (Mecklenburg-Vorpommern and Schleswig-Holstein Federal Lands), Poland, Kaliningrad oblast of RF and Lithuania with total area 137,300 thous. ha. For this research databases of FAO, EUROSTAT and National Statistics Departments of studied countries were used.

\section{Results}

\subsection{The main trends of distribution and changes of UAL in EU and Baltic Sea region countries}

The shrinking of agricultural land was observed also in older EU member countries (EU-15), but this process was not drastic (Fig.1). The UAL for most of EU-15 decreased by $2.5 \%$ between 1990 and 2000, affecting mainly permanent grasslands and permanent crops, not the arable land crops. The total number of livestock units was quite stable from 1990 to 2000, but trends vary for different livestock types and regions. In 1990, $44 \%$ of the agricultural area of EU-15 was managed by high-input farms, but this decreased to $37 \%$ in 2000 . Low-input farms occupied the lowest share of the agricultural area (26\%) but this share increased to $28 \%$ in 2000 . In some regions the livestock stocking density has increased by more than $10 \%$ mainly due to higher pig stocking density in Denmark, northern Germany, and north-eastern Spain. And there was indicated that Spain had large land cover flows from forest/seminatural land to agriculture and from agriculture to forest/semi-natural land. Italy and Portugal showed land cover flow only from agriculture to forest/semi-natural land (EEA..., 2005). At the same time, there was an active participation of farmers of EU-15 in the different environment protection schemes, and this also decreased the shrinking of UAL. Almost one-quarter of all utilised farmland in the EU-15 has been included in an agri-environment scheme, although this figure varies greatly among the Member States in 2002. 
The changes of UAL in all agricultural farms/holdings of studied nine Baltic sea region countries can be seen from the Table 1.

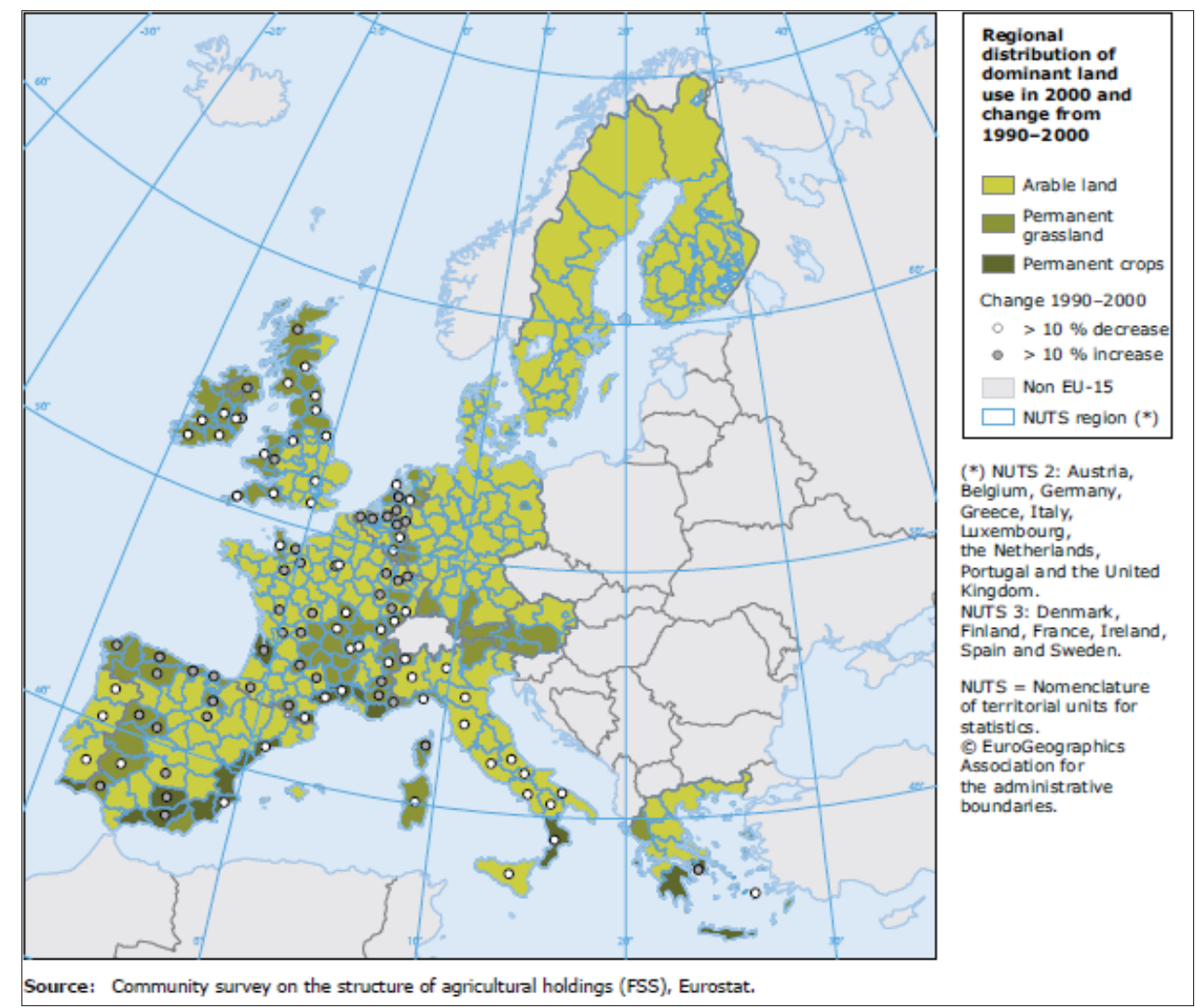

Figure 1. Regional importance of the dominant agricultural land uses and the trend 1990-2000 Source: EEA, 2005

Table 1. The changes of UAL area in thous. ha and \% in all agricultural farms/holdings of 9 Baltic sea region countries from 1993 to 2008

\begin{tabular}{|l|c|c|c|c|}
\hline \multirow{2}{*}{ Country/region } & \multicolumn{2}{|c|}{ Thousands ha } & Difference in 2008 as to the 1993 \\
\cline { 2 - 5 } & $\mathbf{1 9 9 3}$ & $\mathbf{2 0 0 8}$ & \pm thous. ha & -2.6 \\
\hline Denmark & 2740 & 2668 & -72 & -42.6 \\
\hline Estonia & 1400 & 803 & -597 & -14.7 \\
\hline Finland & 2692 & 2297 & -395 & -11.4 \\
\hline Germany* & 2656 & 2352 & -304 & -27.0 \\
\hline Kaliningrad oblast (RF) ** & 580 & 423 & -157 & -27.9 \\
\hline Latvia & 2530 & 1825 & -705 & -24.2 \\
\hline Lithuania & 3524 & 2672 & -852 & -13.7 \\
\hline Poland & 18715 & 16154 & -2561 & -8.0 \\
\hline Sweden & 3361 & 3093 & -268 & -15.5 \\
\hline Total/average & 38198 & 32287 & -5911 & \\
\hline
\end{tabular}

Note: * Mecklenburg-Vorpommern and Schleswig-Holstein, data for 1995 and 2008 ** For Kaliningrad oblast data for 1995 (Bučiene, 2002) and 2005 
The shrinking of UAL took place in all studied countries of Baltic Sea region: it decreased by almost $16 \%$ during the research period in the region. However the grouping of countries according to the shrinking rate has revealed some differences of this process (Fig. 2).

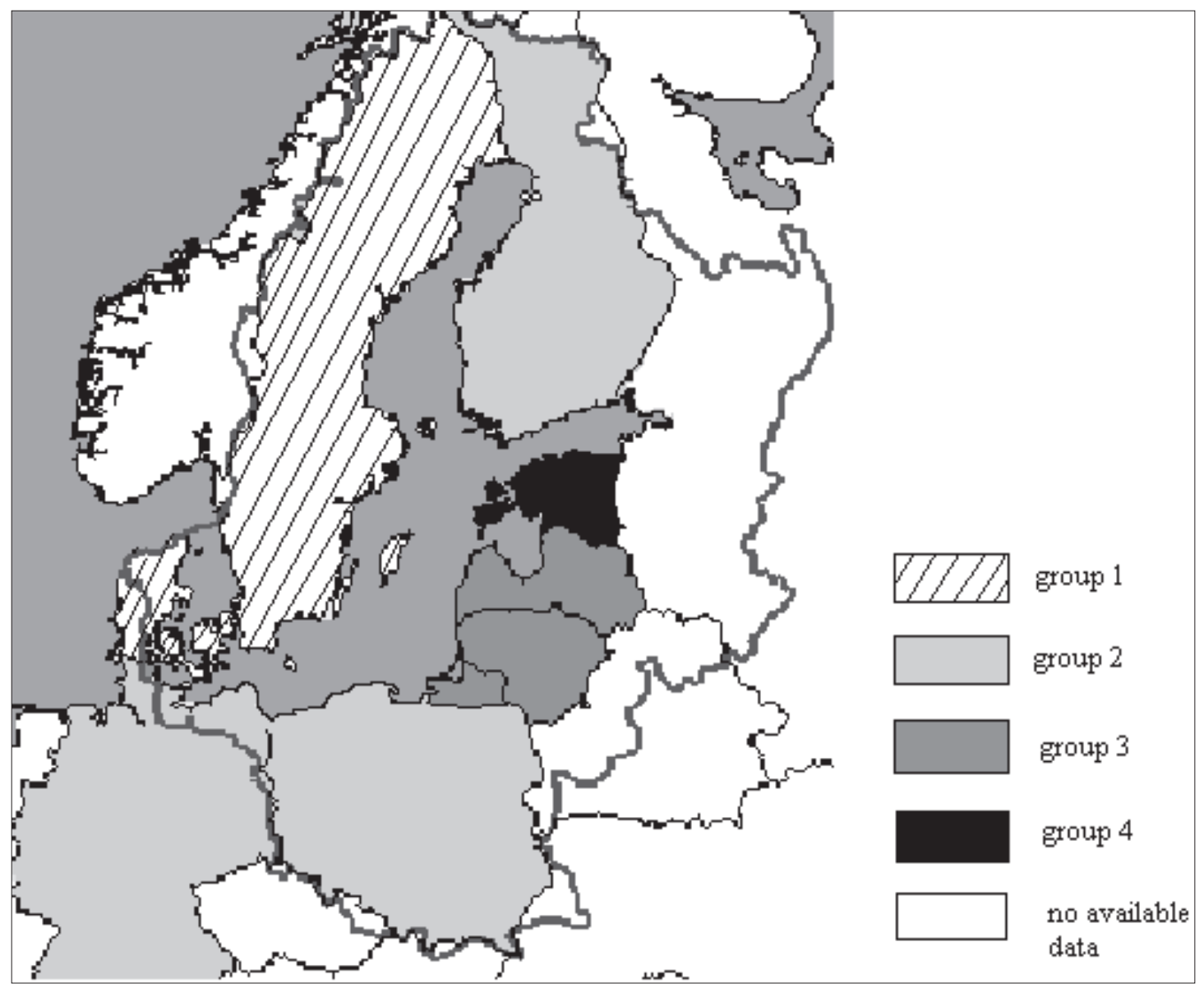

Figure 2. The main groups of Baltic sea region countries with different shrinking rate of UAL

The least decrease in UAL during the studied period was characteristic to Denmark (about $3 \%$ ) and Sweden $(8 \%$ ) (group 1). The group 2 (North Germany, Poland, Finland) distinguished with decrease of UAL by $13 \%$ on the average. The area of UAL was shrunk by $26 \%$ in the group 3 (Lithuania, Kaliningrad oblast of $\mathrm{RF}$, Latvia) on the average, and the country, which experienced the largest shrinkage - almost $43 \%$ - was Estonia (group 4).

\subsection{Recent trends of shrinking rate of utilised arable land area}

The largest areas of arable land in absolute figures are characteristic to Germany and Poland, however as to the $\%$ of total land area, the leader country is Denmark (about $57 \%$ ), and the second two countries are Poland and Germany (Bučiene, 2010: 11). Lithuania remains in the fourth place (almost $29 \%$ ). The arable land has shrunk from 1993 to 2008 by $14 \%$ for whole the region; however there were differences between the countries in shrinking rate (Table 2). 
Table 2. The changes of utilised arable land area in thous. ha and in $\%$ in all agricultural farms/holdings of 9 Baltic sea region countries from 1993 to 2008

\begin{tabular}{|l|l|l|l|l|}
\hline \multirow{2}{*}{ Country/region } & \multicolumn{2}{l|}{ Thousands ha } & \multicolumn{2}{l|}{ Difference in 2008 as to the 1993 } \\
\cline { 2 - 5 } & $\mathbf{1 9 9 3}$ & $\mathbf{2 0 0 8}$ & $\mathbf{\pm}$ thous.ha & $\pm \mathbf{\%}$ \\
\hline Denmark & 2540 & 2400 & -140 & -5.5 \\
\hline Estonia & 1114 & 598 & -516 & -46.3 \\
\hline Finland & 2580 & 2256 & -324 & -12.6 \\
\hline Germany* & 1963 & 1755 & -208 & -10.6 \\
\hline Kaliningrad oblast (RF) ** & 350 & 223 & -127 & -36.3 \\
\hline Latvia & 1687 & 1170 & -517 & -30.6 \\
\hline Lithuania & 2300 & 1862 & -438 & -19.0 \\
\hline Poland & 14305 & 12571 & -1734 & -12.1 \\
\hline Sweden & 2780 & 2626 & -154 & -5.5 \\
\hline Total/average & 29619 & 25461 & -4158 & -14.0 \\
\hline
\end{tabular}

Note: * Mecklenburg-Vorpommern and Schleswig-Holstein, data for 1995 and 2008

** For Kaliningrad oblast data for 1995 (Bučiené, 2002) and 2005

Thus countries with the least shrinkage were again two: Denmark and Sweden (about $6 \%$ ). The second group of 4 countries (North Germany, Poland, Finland and Lithuania) showed the trend to decrease from 10 to $20 \%$. The third group with 2 countries (Latvia and Kaliningrad oblast of RF) was distinguished by the shrinking of arable land area from 20 to $30 \%$. And again, the country, which showed the largest shrinkage of utilised arable land, was Estonia (about $46 \%$ ).

2.3. Recent trends of utilised area under meadows and pastures

The largest areas under the permanent grassland of total land area in the Baltic sea region were typical for North Germany, Lithuania, Poland and Latvia (Bučienė, 2010:11), however Denmark was the only country in the region, where the area under the meadows and pastures increased from 1993 to 2008 (Table 3). In other countries there was evident shrinkage, which varied from $9 \%$ in Kaliningrad oblast of RF to almost $69 \%$ in Finland (with about $21 \%$ on the average).

Table 3. The changes of utilised meadows and pastures in thous. ha and in $\%$ in all agricultural farms/holdings of 9 Baltic sea region countries from 1993 to 2008

\begin{tabular}{|l|c|c|c|c|}
\hline \multirow{2}{*}{ Country/region } & \multicolumn{2}{|c|}{ Thousands ha } & Difference in 2008 as to the 1993 \\
\cline { 2 - 5 } & $\mathbf{1 9 9 3}$ & $\mathbf{2 0 0 8}$ & \pm thous. ha & $\pm \%$ \\
\hline Denmark & 197 & 261 & 64 & 32.5 \\
\hline Estonia & 243 & 197 & -46 & -18.9 \\
\hline Finland & 106 & 33 & -73 & -68.9 \\
\hline Germany* & 690 & 590 & -100 & -14.5 \\
\hline Kaliningrad oblast (RF) ** & 220 & 200 & -20 & -9.1 \\
\hline Latvia & 819 & 648 & -171 & -20.9 \\
\hline Lithuania & 1173 & 783 & -390 & -33.2 \\
\hline Poland & 4047 & 3184 & -863 & -21.3 \\
\hline Sweden & 576 & 458 & -118 & -20.5 \\
\hline Total/average & 8071 & 6354 & -1717 & -21.3 \\
\hline
\end{tabular}

Note: * Mecklenburg-Vorpommern and Schleswig-Holstein, data for 1995 and 2008

** For Kaliningrad oblast data for1995 (Bučiene, 2002) and 2005 
In Lithuania the majority of utilised meadows and pastures are concentrated in private farms: from 24 to $43 \%$ (Kazakevičius, 2011: 98). Tat shows that private farms are creating more diverse and more sustainable rural landscape in Lithuania, than the large agricultural companies with higher farming specialisation and more intensive land use for arable crops.

2.4. The ratio between utilised arable land and area under the utilised meadows and pastures

The higher values of this ratio show the more intensive land use and farming, and in opposite, the lower values show the more extensive land use and farming, but at the same time more diverse landscape. Calculation results are presented in Table 4.

The calculations show the different trends in different countries. In general the ratio increased from 6.5 to 10.9 showing some tendency to the more intensive farming even the UAL area was shrunk. However more evident differences between countries can be seen from the Fig.3. It shows, that in the group 1 (Estonia, Kaliningrad oblast of RF, Denmark) there was a trend towards more extensive land use, and the same but less expressed trend was observed in North Germany and Latvia (group 2). Differently, in the groups 3 (Lithuania, Sweden and Poland) and 4 (Finland), the ratio increased showing the trend towards more intensive land use and farming.

Table 4. The changes of ratio between arable land and area under the utilised meadows and pastures all agricultural farms/holdings of 9 Baltic sea region countries from 1993 to 2008

\begin{tabular}{|l|c|c|c|c|}
\hline \multirow{2}{*}{ Country/region } & \multicolumn{2}{|c|}{ Ratio } & \multicolumn{2}{c|}{ Difference in 2008 as to the 1993 } \\
\cline { 2 - 5 } & $\mathbf{1 9 9 3}$ & $\mathbf{2 0 0 8}$ & \pm ratio & $\pm \%$ \\
\hline Denmark & 12.9 & 9.2 & -3.7 & -29 \\
\hline Estonia & 4.6 & 3.0 & -1.6 & -35 \\
\hline Finland & 24.3 & 68.4 & 44.1 & -7 \\
\hline Germany* & 2.8 & 3.0 & 0.2 & -31 \\
\hline Kaliningrad oblast (RF) ** & 1.6 & 1.1 & -0.5 & -14 \\
\hline Latvia & 2.1 & 1.8 & -0.3 & 20 \\
\hline Lithuania & 2.0 & 2.4 & 0.4 & 11 \\
\hline Poland & 3.5 & 3.9 & 0.4 & 19 \\
\hline Sweden & 4.8 & 5.7 & 0.9 & 68 \\
\hline Average & 6.5 & 10.9 & 4.4 & \\
\hline
\end{tabular}

Note: * Mecklenburg-Vorpommern and Schleswig-Holstein, data for 1995 and 2008

** For Kaliningrad oblast data for 1995 (Bučiene, 2002) and 2005

As the other research conducted in the Middle of Lithuania revealed the productivity point of agricultural farming lands, sensitivity of soils to erosion processes and favorable conditions for the development of large farms and agricultural farming land areas - these are the factors having not much impact on the changing processes of farming lands. Land users, human migration processes in rural areas, the origin of abandoned, uncultivated land areas and economic factors have the largest impact on the change of farming land at present (Atkoceviciene et al., 2011:35). In order to make more grounded conclusions it is necessary to analyse these reasons for other Baltic Sea region countries in further research. 


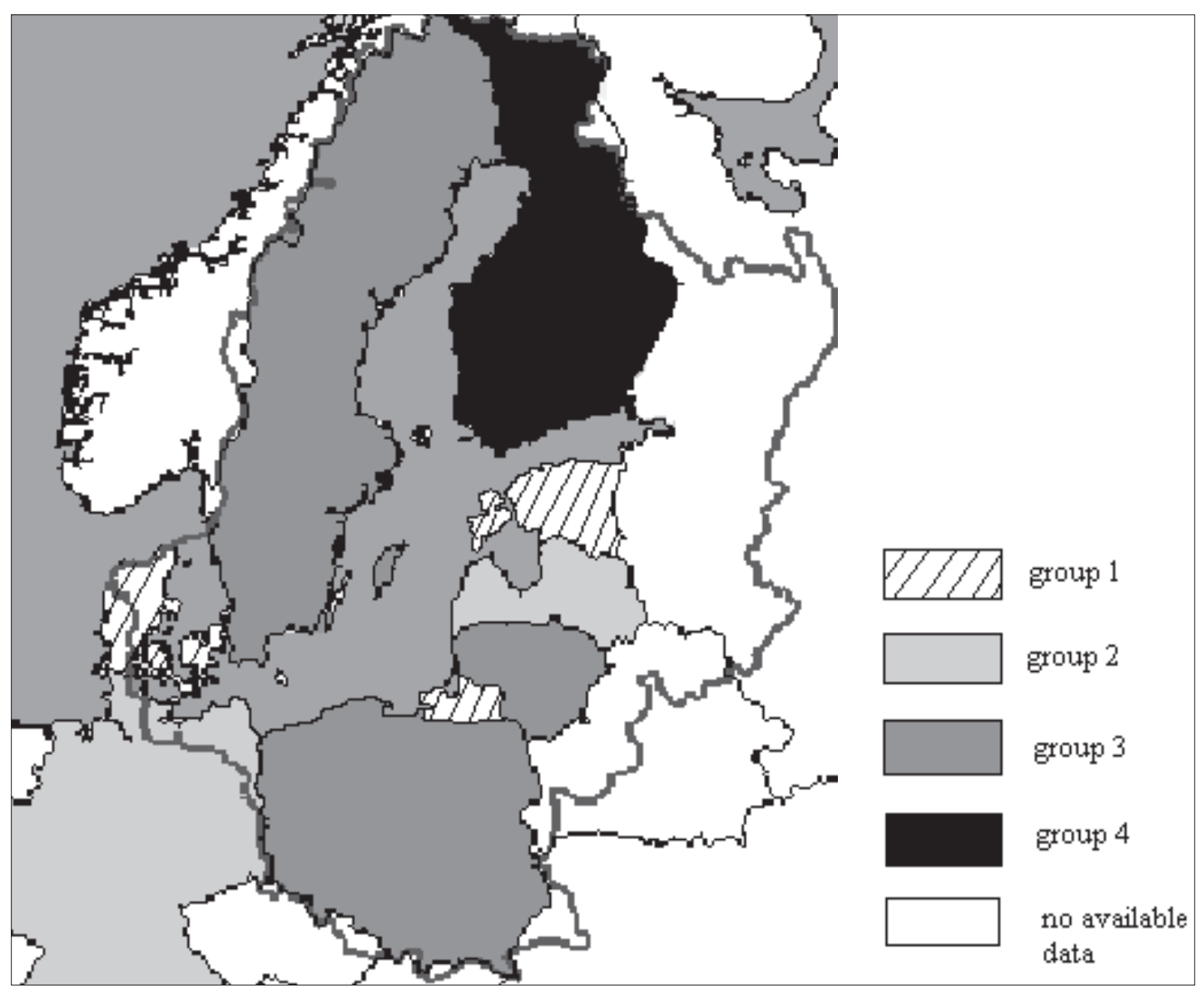

Figure 3. The main groups of Baltic Sea region countries with different trends of changed ratio between utilized arable land area and area under the utilized meadows and pastures, 1993-2008

\section{Conclusions}

After the analysis of results above, few conclusions might be drawn:

1. The determined shrinking of UAL in nine studied countries from 1993 to 2008 was almost $16 \%$. The highest shrinking rate was determined in Estonia, followed by Latvia, Kaliningrad oblast of RF and Lithuania. For arable land it was characteristic to shrink as it is shown mostly also in Estonia, followed by Latvia and Kaliningrad oblast of RF.

2. Denmark was the only country in the region, where the area under the meadows and pastures increased from 1993 to 2008 (by $32 \%$ ), and Finland was one, where it decreased mostly (by almost $69 \%$ ). In the rest of countries the area under the utilised meadows and pastures decreased from 14 to $33 \%$, and arable land area decreased from 12 to $19 \%$.

3. Two main trends of changes in ratio between the area of utilised arable land and area under the meadows and pastures were determined in the research region: 1). Trend towards extensive land use and farming - mostly evident in Estonia, Kaliningrad oblast of RF, Denmark, and less evident in North Germany and Latvia; 2). Trend towards more intensive land use and farming - mostly evident in Finland and a little less evident in Lithuania, Sweden and Poland. 


\section{References}

Agriculture \& Fisheries. Website: http://economy.gov39.ru/en/investicionnye-vozmozhnosti/poisk-investora/poisk-pobaze/index.php (visited 10th of January, 2012).

Andersen, E. (ed.) (2003). Developing a high nature value farming area indicator. Internal report EEA. European Environment Agency, Copenhagen.

Atkoceviciene, V., Gudritiene, D., Dudoniene, V. (2011). The analysis on the change of farming lands in the territory of Middle Lithuania. Baltic surveiying'11. Proceedings International Scientific Conference of Agriculture Universities of Baltic States, 11th - 13th of May, 2011. Jelgava, p. 25-36.

Baldock, D., Beaufoy, G., Brouwer, F., Godeschalk, F. (1996). Farming at the margins: Abandonment or redeployment of agricultural land in Europe. IEEP/LEI-DLO, London/Den Haag.

Bučiené, A. (2002). Overview of rural population demographic situation, land use and spheres of activity in the Baltic Sea region. Tiltai. Brücken. Bridges. Scientific paper of Klaipeda University, vol. 2, p. 11-18.

Bučienė, A. (2003). Žemdirbystès sistemu ekologiniai ryšiai. Monografija. Klaipėda: Klaipėdos universiteto leidykla.

Bučienè, A. (2009). Biogenu N ir P išplova Lietuvos žemumu dirvožemiuose. Habilitacijos procedūrai teikiamų mokslo darbų apžvalga. Fiziniai mokslai, geografija (06P). Vilnius.

Bučiene, A. (2010). Ecological agriculture and sustainable development in the Baltic Sea region. Human resources the main factor of regional development, Journal of Social sciences, No. 3. Klaipeda university, p. 7-14.

Contemporary changes of agriculture in East-Central Europe. (2008). J. Banski, M. Bednarek (eds.). Rural Studies, Vol. 15. Warsaw.

Dobele, A. (2004). Use of land resources in Latvia. Approbation, presentation and resume of PhD Paper, Jelgava, Latvia University of Agriculture, Faculty of Economics, Department of Business and management.

Website: http//www.Dobele_ang.doc (visited 9th January, 2012).

EEA Signals (2004). A European Environment Agency update on selected issues. Copenhagen. Website: http://www.eea.europa.eu/publications/signals-2004/ENSignals2004web.pdf (visited 11th January, 2012).

EEA. (2005). Agriculture and environment in EU-15 - the IRENA indicator report.

Europe in figures. (2009). Agriculture, forestry and fishery - Eurostat yearbook.

Kazakevičius, Z. (2011). Žemès išteklių naudojimo Lietuvos ūkininkų ūkiuose vertinimas. Management theory and studies for rural business and infrastructure development, Nr. 3 (27). Research papers, p. 94-103.

Korneevets, V. (1997). Agriculture in North-Western Russia. A sustainable Baltic region. Food and Fibres. Sustainable agriculture, forestry and fishery. B. Bodin, S. Ebbersten (eds.). Swedish University of Agricultural Sciences. Uppsala University, p. 23-25.

Mücher, S., Wascher, D. (2007). European landscape characterisation. Europe's living landscapes. Essays on exploring our identity in the countryside. LANDSCAPE EUROPE / KNNV. B. Pedroli, A. Van Doorn, G. De Blust, M. L. Paracchini, D. Wascher, F. Bunce (eds.). Website: http://www.landscape-europe.net/files/37-43\%2520correctie.pdf (visited 11th January, 2012), p. 38-43.

Nikodemus, O., Bell, S., Penēze, Z., Krūze, I. (2010). The influence of European Union single area payments and less favoured area payments on the Latvian landscape. Europ. Countrys, Vol. 1, p. 25-41.

Statistics Division FAO. (2010). Website: http://www.fao.org/fileadmin/templates/ess/ess_test_folder/Publications/ yearbook_2010/a04.xls (visited on 8th January, 2012).

Sustainable agriculture. (2012). Ch. Jakobsson (ed.). Ecosystem Health and Sustainable Agriculture, Vol. 1. The Baltic University Programme, Uppsala University.

Towards a Baltic sea unaffected by eutrophication. (2007). HELCOM Overview, HELCOM Ministerial Meeting Krakow, Poland, 15 November 2007. Website: http://www.helcom.fi/stc/files/Krakow2007/Eutrophication_MM2007. pdf (visited on 9th January, 2012).

Vinokurov, E. (2007). Kaliningrad: Enclaves and Economic Integration. Thinking ahead for Europe, Special Report, CEPS (Centre for European Policy Studies). Website: http://www.ceps.be (visited on 9th January, 2012).

Website: www.stat.gov.de

Website: www.stat.gov.ee

Website: www.stat.gov.fi

Website: www.stat.gov.lt

Website: www.stat.gov.lv

Website: www.stat.gov.pl

Website: www.stat.gov.se (all visited on 9th January 2012).

Целевая программа Калининградской области «Осножные направления развития агропромышиенного комплекса Калининградской области на 2007-2016 годыр». Приложение к постановлению Правительства Калининградской области от 2006 года (in Russian). 


\section{NAUDOJAMŲ ŽEMĖS ŪKIO NAUDMENŲ IR JŲ KOMPONENTU MAŽĖJIO TEMPAI BALTIJOS REGIONO ŠALYSE}

AngeliJa BuČIENĖ

Klaipėdos universitetas (Lietuva)

\section{Santrauka}

Erdviniai ir laikiniai žemėnaudos pokyčiai reikšmingi tiriant kaimo kraštovaizdžio kaitą tiek regioniniugeografiniu, tiek ir aplinkosauginiu aspektais. Nagrinejjamame Baltijos regione (9 šalys, kur Rusijos Federacijai atstovauja Kaliningrado sritis), naudojamos žemès ūkio naudmenos vidutiniškai sudaro apie $34 \%$ bendrojo regiono ploto. Atlikus tyrimą nustatyta bendra tendencija - naudojamų žemės ūkio naudmenų ploto mažèjimas nuo 1993 m. iki 2008 m. - 16 \% visame regione (mažiausias sumažèjimo tempas užfiksuotas Danijoje $-3 \%$, didžiausias Estijoje - $43 \%$ ). Tyrimais nustatytas ir skirtingas naudojamų žemès ūkio naudmenų bei jos komponentų - ariamosios žemès, pievų ir ganyklų - mažéjimo tempas pavienėse Baltijos regiono šalyse. Be Estijos, dideliu naudojamų žemès ūkio naudmenų plotų mažejimu per minètą laikotarpi pasižymėjo Latvija, RF Kaliningrado sritis ir Lietuva. Šiose šalyse labiausiai sumažèjo ariamosios žemės plotai. Danija buvo vienintelè šalis regione, kurioje per 1993-2008 m. padidejjo naudojamų pievų ir ganyklų plotas (32\%), tuo tarpu Suomijoje jis sumažèjo labiausiai - net $69 \%$. Likusiose šalyse (šiaurinèje Vokietijos dalyje, Lenkijoje, Švedijoje) naudojamų pievų ir ganyklų plotai sumažejo nuo 14 iki 33\%, ariamosios žemès plotai - nuo 12 iki $19 \%$, atsižvelgiant ị šalị.

Išryškėjo dvi naudojamų žemės ūkio naudmenų kaitos tendencijos regione: 1) žemès ūkio ekstensyvèjimo tendencija, kai sparčiau traukèsi ariamosios žemès plotai, lyginant su pievų ir ganyklų plotais; 2) žemės ūkio intensyvèjimo tendencija, kai ariamosios žemès dalis, nors ir traukẻsi naudojamų žemès ūkio naudmenu plotai, santykinai padidejo. Pirmoji tendencija akivaizdi Estijoje, RF Kaliningrado srityje ir Danijoje, šiek tiek mažiau ryški šiaurinèje Vokietijoje ir Latvijoje, antroji akivaizdi Suomijoje, šiek tiek mažiau ryški Lietuvoje, Švedijoje ir Lenkijoje.

PAGRINDINIAI ŽODŽIAI: naudojamos žemès ūkio naudmenos, ariamoji žemė, pievos ir ganyklos, mažejimo tempas

JEL KODAI: Q 16, Q 15. 